\title{
ARTICLE \\ Biochemical composition of the nereidid Perinereis cultrifera from the Egyptian Mediterranean Coast
}

\author{
Composición bioquímica del nereidido Perinereis cultrifera de la costa Mediterránea de Egipto
}

\author{
Mohamed Moussa Dorgham ${ }^{1}$, Rasha Hamdy ${ }^{1}$, Hoda Hassan ${ }^{1}$ \\ Al-Rasheedy ${ }^{1}$ and Manal Mohamed Atta ${ }^{1}$
}

\begin{abstract}
'Department of Oceanography, Faculty of Science, Alexandria University, Alexandria, 21511, Egypt. mdorgham1947@ yahoo.com
Resumen.- El presente estudio documenta la composición bioquímica del poliqueto nereidido Perinereis cultrifera (carbohidratos, proteínas, lípidos, ácidos grasos y amino ácidos) recolectados en un área somera de la costa de Alejandría, Mediterráneo suroriental. Los resultados de este estudio muestran que P. cultrifera contiene $85,34-87,76 \%$ de peso húmedo como agua, 14,7$20,53 \%$ de peso seco (DW) como ceniza, 8,3-14,84\% del DW como carbohidratos, 57,33-59,9\% de DW como proteína y $11,59-$ 13,36\% de DW como lípidos. Los ácidos grasos totales variaron estacionalmente desde 45,9 a $100 \%$ de lípidos totales con dominancia absoluta (37,44-91,53\%) del ácido eicosapentanoico (EPA) (C20:5n-3), acompañado por una pequeña cantidad de ácido esteárico (C18:0). Se identificaron 18 amino ácidos, incluyendo 10 esenciales (59,62-61,02\% de proteína) y 8 no esenciales (38,98-40,38\% de proteína).
\end{abstract}

Palabras clave: Carbohidratos, lípidos, ácidos grasos, amino ácidos

\begin{abstract}
The present study documents the seasonal biochemical composition of the nereidid polychaete Perinereis cultrifera (carbohydrates, protein, lipids, fatty acids and amino acids) collected from a shallow area on the Alexandria coast, southeast Mediterranean. The results of this study showed that P. cultrifera contained $85.34-87.76 \%$ of the wet weight as water, $14.7-20.53 \%$ of dry weight (DW) as ash, 8.3-14.84\% of DW as carbohydrates, $57.33-59.9 \%$ of DW as protein and $11.59-13.36 \%$ of DW as lipids. The total fatty acids varied seasonally from 45.9 to $100 \%$ of the total lipids with the absolute dominance (37.44-91.53\%) of the polyunsaturated eicosapentaenoic acid (EPA) (C20:5n-3), accompanied by a small amount of the saturate stearic acid (C18:0). Eighteen amino acids were identified, including 10 essential (59.62-61.02\% of protein) and 8 nonessential (38.98-40.38\% of protein).
\end{abstract}

Key words: Carbohydrates, lipids, fatty acids, amino acids

\section{INTRODUCTION}

The intensive harvest of wild polychaetes as food in aquaculture and as fishing bait has caused pressures on natural stocks and habitats, whereas polychaete aquaculture appears to be the best way to meet increasing demands of these animals (Poltana et al. 2007, Palmer 2008, 2011).

The nutritional value of polychaetes has been specifically attributed to their high content of PUFAs (Olive 1999, Shucksmith et al. 2006) which have been proved to be an important vector to transfer essential fatty acids to fish and crustaceans in aquaculture (Bischoff et al. 2009, Palmer et al. 2014). There have been many recent studies documenting the nutritional benefits of polychaetes for aquaculture species, such as satisfactory food intake and reproductive performance in broodstock sole (Cardinaletti et al. 2009), provision of PUFAs like AA, EPA, DHA, and the high n3:n6 ratio that help in fertilization, hatch rates and spawning frequency in the shrimp Penaeus monodon broodstock (Huang et al. 2008) and for fish such as sea bream (Bell \& Sargent 2003, Caballero et al. 2004).

The choice of a worm species for mass culture depends upon its nutritive value, which can be evaluated through the estimation of the main biochemical components such as proteins and lipids and their breakdown into specific fatty and amino acids.

Palmer et al. (2014) provides a very recent comparison of some important nutritional values of commercially relevant polychaetes, and other researchers have studied how seasonal and environmental factors can affect the biochemical compositions of a range of species (Fernandez 1998, Danovaro et al. 1999, Mayzaud et al. 1999). In particular, there have been numerous studies regarding the nereidid polychaete Perinereis cultrifera (Grube, 1840). These studies have focused on the synthesis of neutral lipids in oocytes (Dhainaut $\&$ Belhamra 1986), their distribution in coelomic constituents 
during oogenesis (Fontaine et al. 1984), the qualitative and quantitative evolution of carbohydrates during oogenesis (Porchet \& Spike 1978), the origin of yolk protein, vitellin (Baert \& Slomianny 1987), and physical-chemical and functional properties of the protein (Musmeci \& Damelio 1985). Others have studied $P$. cultrifera as biomarkers for environmental quality (Guemouda et al. 2014), and the effect of amylase on their growth, biochemical composition and fatty acid profile (Elayaraja et al. 2011).

The aim of the present work was to add further knowledge about the biochemical composition of $P$. cultrifera from the Alexandria coast through seasonal study, in order to evaluate its nutritive value as a life feed in aquaculture.

\section{Materials AND METHODS}

Worms were collected seasonally in summer (August), autumn (October), winter (January) and spring (April) during August 2009 to July 2010 at 07:00-08:00 h from the algae and associated fouling covering hard-bottom within a depth range of 30-60 cm at El Mex (Fig. 1), west of the Alexandria coast, Egypt (Table 1). Within $2 \mathrm{~h}$ after the samples collection, worms were isolated from the benthos and divided into 2 subsamples. One subsample was used for determining the water and ash contents, and the other was frozen at $-80^{\circ} \mathrm{C}$ in a liquid nitrogen freezer prior to biochemical analyses. After thawing, the later subsample was subdivided into 4 subsamples to determine their biochemical composition.

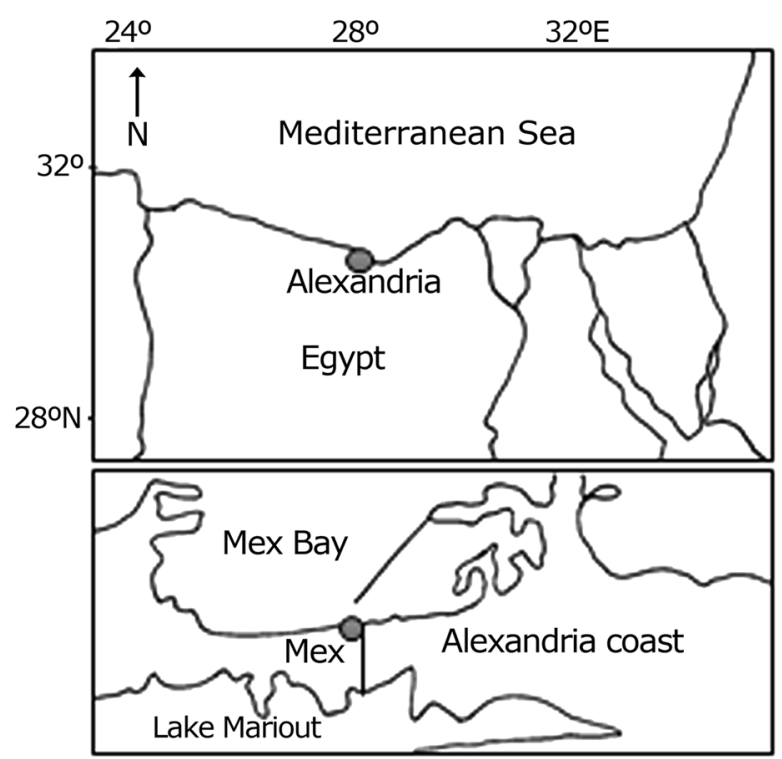

Figure 1. Location of the sampling site at Alexandria, Egypt / Ubicación del lugar de muestreo en Alejandría, Egipto
Table 1. The biometric data and number of worms used in the study (Imm: immature) / Datos biométricos y número de poliquetos utilizados en el estudio (Imm: inmaduro)

\begin{tabular}{|c|c|c|c|c|c|}
\hline \multirow{3}{*}{ Date } & \multicolumn{3}{|c|}{ Sex } & \multirow{3}{*}{$\begin{array}{l}\text { Length } \\
\text { range } \\
\text { (cm) }\end{array}$} & \multirow{3}{*}{$\begin{array}{l}\text { Weight } \\
\text { range } \\
\text { (g) }\end{array}$} \\
\hline & Imm. & 우 & $\hat{0}$ & & \\
\hline & \multicolumn{3}{|c|}{$\mathrm{N}^{\mathrm{o}}$ of worms } & & \\
\hline Summer (August) & 3 & 3 & 1 & $1.85-3.8$ & $0.011-0.108$ \\
\hline Autumn (October) & 13 & 1 & 2 & $2.4-5.0$ & $0.023-0.161$ \\
\hline Winter (January) & 13 & 9 & 0 & $2.6-7.4$ & $0.023-0.510$ \\
\hline Spring (April) & 7 & 5 & 0 & $2.0-7.0$ & $0.017-0.501$ \\
\hline
\end{tabular}

The water content was estimated by drying a known weight of worms at $105^{\circ} \mathrm{C}$ for $24 \mathrm{~h}$ to constant weight. Ash content was determined by burning the sample at $500^{\circ} \mathrm{C}$ in a muffle furnace for $6 \mathrm{~h}$. Total protein was extracted following Rossi $e t$ al. (2001) by $0.5 \mathrm{~N} \mathrm{NaOH}$ for $4 \mathrm{~h}$ and measured calorimetrically according to Gornall et al. (1949).

Lipids were extracted with a polar solvent mixture consisting of chloroform, methanol and water (1:2:0.8), and fat content was determined by weighing the lipids after solvent evaporation (Bligh \& Dyer 1959). The estimation of carbohydrates was undertaken according to James (1995), using the following equation:

Carbohydrates $\%=100-($ moisture $\%+$ protein $\%+\operatorname{lipid} \%+$ ash \%).

Determination of fatty acids was carried out by dissolving lipid samples in a methanol solution of potassium hydroxide (1M) and the produced mixture (fatty acid methyl esters) was evaporated to dryness, then dissolved in methanol and injected into the HPLC. The separation of fatty acids was done in HPLC (Agilent-1200) using C18 reversed-phase column $(25 \mathrm{~cm})$ and a UV detector at a flow rate of $1 \mathrm{ml} \mathrm{min}^{-1}$ at room temperature of a 97:3 methanol:water eluent mixture. Amino acids were determined using Dionex (ICS-3000) following the technique describe by Crafts et al. (2012). Amino acids are expressed as a percentage of the total protein, and specific fatty acids are expressed as a percentage of the total lipids.

Some environmental parameters of the surrounding water were measured concurrently with the polychaete sampling, including temperature, salinity, $\mathrm{pH}$, dissolved oxygen (DO) and biochemical oxygen demand (BOD). The water temperature and $\mathrm{pH}$ were determined in the field, using a digital portable HANNA $10^{\mathrm{pH}} ; \mathrm{pH}-{ }^{\circ} \mathrm{C}$ Meter, while salinity was measured by a calibrated Beckman Induction Salinometer (Model RS-7C). Dissolved oxygen (DO) and biochemical oxygen demand (BOD) were measured according to the Winkler method described by Strickland \& Parsons (1975). 
Correlations between the biochemical constituents and environmental parameters were calculated. The univariate statistical analysis was used to calculate the mean and standard deviation (SD) of the seasonal values of different biochemical constituents.

\section{Results}

\section{Physico-chemical conditions}

As shown in Table 2, water temperature displayed wide seasonal variations, from $18.9^{\circ} \mathrm{C}$ in winter and $28.9^{\circ} \mathrm{C}$ in summer. Salinity fluctuated between a minimum of $29.7 \mathrm{in}$ summer and a maximum of 39.8 in autumn, mainly due to the discharge of the brackish water from the adjacent Lake Mariout. Neither pH nor DO showed seasonal variations, except for the relatively low values of DO in autumn. The BOD was also relatively low in autumn and spring, increasing pronouncedly in winter and reaching the maximum value in summer (Table 2).

\section{Biochemical ANALYSES}

The water content in $P$. cultrifera showed slight seasonal differences (85.34-87.76\% of wet weight) (Fig. 2), while greater comparative differences were recorded in ash contents between the minimum (14.7\%) in autumn and the maximum $(20.53 \%)$ in spring (Fig 3). Total lipids varied within a seasonal range of 11.6$13.4 \%$ ofDW, displaying the lowest value in winter and the highest in summer. Total protein had narrow seasonal variations, with the highest value (59.9\%) in winter, and slightly lower values in the other seasons (spring: 55.1\%, summer: 55.6\%, autumn: 57.3\%). Carbohydrate showed similarlynarrow seasonal variations, being $14.8 \%$ of DW in autumn, decreased to $8.3 \%$ in winter, and then sustained comparatively higher similar values (12.5 and 12.6\%) in spring and summer respectively (Fig. 3). Carbohydrates displayed negative significant correlation with DO $(\mathrm{r}=-0.9966$, $P<0.05)$.

Table 2. Seasonal values of the physico-chemical parameters at El Mex (DO: dissolved oxygen, BOD: biochemical oxygen demand) / Valores estacionales de los parámetros físico-químicos en El Mex (DO: oxígeno disuelto, BOD: demanda bioquímica de oxígeno)

\begin{tabular}{lccccc}
\hline \multicolumn{1}{c}{ Season } & $\begin{array}{c}\text { Temp } \\
\left({ }^{\circ} \mathrm{C}\right)\end{array}$ & Salinity & $\mathrm{pH}$ & $\begin{array}{c}\mathrm{DO} \\
\left(\mathrm{mg} \mathrm{l}^{-1}\right)\end{array}$ & $\begin{array}{c}\mathrm{BOD} \\
\left(\mathrm{mg} \mathrm{l}^{-1}\right)\end{array}$ \\
\hline Summer (August) & 28.9 & 29.7 & 8.21 & 8.53 & 6.21 \\
Autumn (October) & 26.3 & 39.8 & 8.10 & 4.40 & 1.11 \\
Winter (January) & 18.9 & 38.7 & 8.30 & 8.90 & 4.38 \\
Spring (April) & 22.6 & 32.6 & 8.20 & 8.20 & 1.77 \\
\hline
\end{tabular}

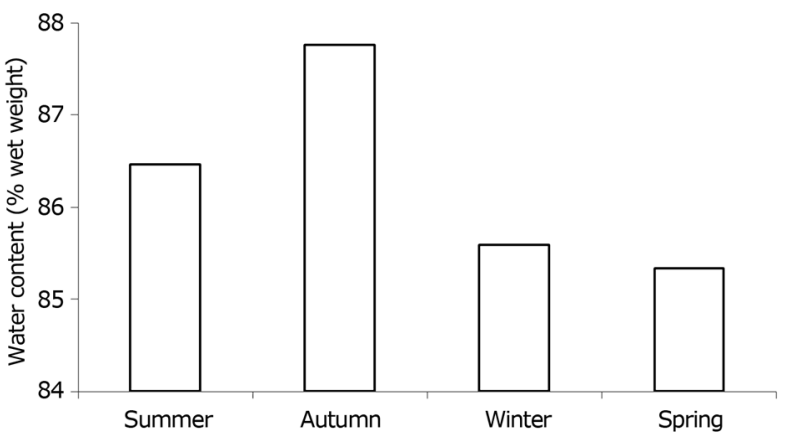

Figure 2. Seasonal percent of water content of Perinereis cultrifera at El Mex, Alexandria, Egypt / Porcentaje estacional del contenido de agua de Perinereis cultrifera en El Mex, Alejandría, Egipto

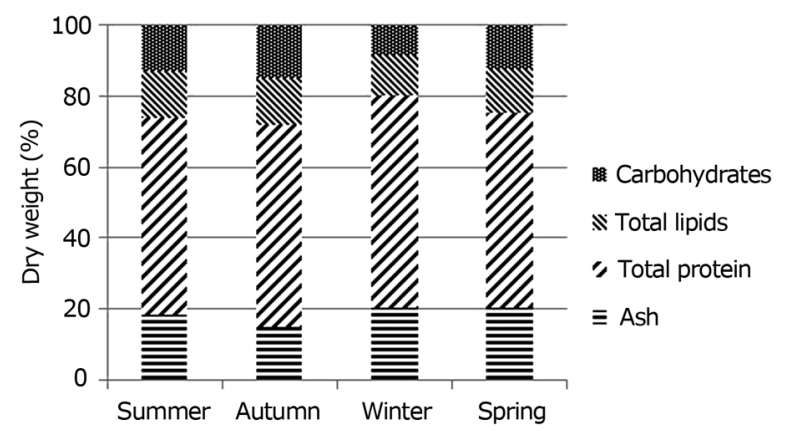

Figure 3. Seasonal percent of contents of ash, total protein, total lipids and carbohydrates in Perinereis cultrifera at El M ex, Alexandria, Egypt / Porcentaje estacional de los contenidos de ceniza, proteína total, lípidos totales y carbohidratos en Perinereis cultrifera en El Mex, Alejandría, Egipto

The profile of the amino acids in P. cultrifera (Table 3) reported 10 essential amino acids (EEA) and 8 nonessential amino acids (NEEA), with the dominance of EAA (59.6-61\% of protein) against NEAA (39.4-40.4\% of protein). Leucine sustained the highest concentration among the EAA, but without observable seasonal differences (32.2-33.8\%), but other EEA displayed relatively high concentrations, like lysine (7.3-8.3\%), methionine (5.2-6\%) and histidine (2.9-4.2\%). The NEAA were dominated by serine, which showed no seasonal differences (16.2-17.1\%), and to a lesser degree glycine (9.8$10.1 \%$ ) and alanine (4.9-5.7\%) (Table 3). Amino acids in $P$. cultrifera had no significant correlation with the environmental conditions, except that of tyrosine and proline with temperature at $P<0.05(\mathrm{r}=0.976$ and -0.968$)$, aspartate with $\mathrm{pH}(\mathrm{r}=-$ 0.956) and glycine with DO (0.954) and Cystine and Glutamate with BOD (-0.992 and 0.960). 
Table 3. Seasonal ranges and mean of the amino acids contents (\% of protein) in Perinereis cultrifera at El Mex (SD=standard deviation) / Rangos y medias estacionales del contenido de amino ácidos (\% de proteína) en Perinereis cultrifera en El Mex (SD= desviación estándar)

\begin{tabular}{|c|c|c|}
\hline Amino acid & Range & Mean \pm SD \\
\hline \multicolumn{3}{|l|}{ EAA } \\
\hline Isoleucine & $1.3-2.07$ & $1.67 \pm 0.342$ \\
\hline Leucine & $32.21-33.70$ & $32.988 \pm 0.641$ \\
\hline Lysine & $7.29-8.31$ & $7.723 \pm 0.438$ \\
\hline Methionine & $5.19-6.03$ & $5.6 \pm 0.356$ \\
\hline Phenylalanine & $0.26-1.30$ & $0.865 \pm 0.457$ \\
\hline Threonine & $2.33-3.39$ & $2.798 \pm 0.452$ \\
\hline Tryptophan & $0.78-2.08$ & $1.435 \pm 0.538$ \\
\hline Valine & $2.34-3.38$ & $2.848 \pm 0.481$ \\
\hline Histidine & $2.86-4.15$ & $3.42 \pm 0.591$ \\
\hline Tyrosine & $0.52-1.82$ & $1.105 \pm 0.577$ \\
\hline Total & $59.62-61.02$ & $60.448 \pm 0.591$ \\
\hline \multicolumn{3}{|l|}{ NEAA } \\
\hline Arginine & $0.78-1.82$ & $1.328 \pm 0.457$ \\
\hline Alanine & $4.92-5.73$ & $5.35 \pm 0.338$ \\
\hline Aspartate & $2.07-3.38$ & $2.743 \pm 0.551$ \\
\hline Cysteine & $0.26-1.04$ & $0.585 \pm 0.390$ \\
\hline Glutamate & $0.78-1.55$ & $1.188 \pm 0.345$ \\
\hline Glycine & $9.09-10.10$ & $9.69 \pm 0.445$ \\
\hline Proline & $1.3-2.59$ & $2.015 \pm 0.572$ \\
\hline Serine & $16.21-17.10$ & $16.65 \pm 0.364$ \\
\hline Total & $38.99-40.36$ & $39.55 \pm 0.579$ \\
\hline EAA / NEAA & $1.5-1.60$ & $1.525 \pm 0.050$ \\
\hline
\end{tabular}

(EEA): essential amino acids

(NEEA): nonessential amino acids

Fatty acids were estimated as total amounts with broad groupings into saturates and unsaturates. As shown in Table 4 the unsaturates were the major component of fatty acids, and were dominated by the polyunsaturate eicosapentaenoic acid, C20:5n-3, which experienced wide seasonal variation (37.4$91.5 \% \pm 23.38$ of total fatty acids), and attained the highest value in autumn and the lowest in spring. The saturates were pronouncedly lower than the unsaturates, having values from $5.5-8.7 \pm 1.527 \%$ and were represented mainly by stearic acid (C18:0) which sustained similar levels in most seasons (8.47$8.7 \%$ ), and comparatively low one in winter (5.5\%).
Table 4. Seasonal ranges and mean of the fatty acids contents (\% of total fatty acids) in Perinereis cultrifera at El Mex (SD= standard deviation) / Rangos y medias estacionales del contenido de ácidos grasos (\% de ácidos grasos totales) en Perinereis cultrifera en El Mex ( $S \mathrm{D}=$ desviación estándar)

\begin{tabular}{lcc}
\hline & Range & Mean \pm SD \\
\hline SFA & $5.5-8.7$ & $7.79 \pm 1.527$ \\
UFA & $37.44-91.53$ & $68.34 \pm 23.388$ \\
Total fatty acids & $45.91-100$ & $76.125 \pm 23.932$
\end{tabular}

SFA: saturated fatty acids

UFA: unsaturated fatty acids

\section{Discussion}

The intensive use of marine polychaetes as fishing bait and for enhancing reproduction in shrimp and fish broodstock in numerous world countries (Palmer et al. 2014) represents a stress on the biodiversity of the benthic communities, particularly polychaete community. These conditions promote the mass culture of polychaetes for commercial use (Palmer 2010, Limsuwatthanathamrong et al. 2012) in aquaculture, whereas they form 5-33\% of shrimp diets (Meunpol et al. 2005, Coman et al. 2007), relative to their advantages and preferences for use over other broodstock feeds (Palmer et al. 2014). The preference of polychaetes as feed for crustaceans is attributed to their contents of a suitable balance of nutrients and several other factors promoting crustacean reproduction (Palmer et al. 2014). Several authors documented the crucial role of high concentrations of polyunsaturated fatty acids in membrane structures, metabolic processes and in vivo supply of sex steroids (e.g., Izquierdo et al. 2001, Nguyen et al. 2012, Palmer 2014). However, the nutritional value of polychaetes as well as other diets can vary with species, season of harvest and life stage(Chimsung 2014).

The present study revealed that $P$. cultrifer $a$ can have a similar biochemical composition to that of many other commercially relevant polychaete species. Its water content (85.34-87.76\% of wet weight) was slightly higher than in Pseudoneries anomala (83.65-84.8\%: Dorgham et al. 2014) but lower than that found in deep pelagic polychaetes, like Poeobius meseres, Pelagobia sp., Tomopteris pacifica, Traviopsis lobifera (89.4-95\%: Thuesen \& Childress 1993). Lower water contents were found in Perinereis helleri, varying between $804.7 \mathrm{~g} \mathrm{~kg}^{-1}$ of wet weight in small worms and $792 \mathrm{~g}$ $\mathrm{kg}^{-1}$ in large worms (Palmer et al. 2014).

Carbohydrates in P. cultrifera displayed levels (8.3-14.8\%) within the ranges reported for other polychaete species, including Laeonereis ankyloseta (9.4\%: Balasubramanian et al. 2012), P. anomala (6.5-18.7\%: Dorgham et al. 2014) and 
Nereis virens (130-170 $\mathrm{g} \mathrm{kg}^{-1}$ : Brown et al. 2011). For $P$. helleri, Palmer et al. (2014) recorded lower values (60-80 g $\left.\mathrm{kg}^{-1}\right)$.

Although Palacios et al. $(1998,1999)$ related carbohydrates to egg glucose levels with larval quality and broodstock condition, Meena et al. (2013) supposed that carbohydrates may be not essential for shrimp broodstock diets. However, carbohydrates have a role in glycogen accumulation in the hepatopancreas and acting as binders and in transport of nutrients in the hemolymph (Harrison 1997).

The protein content in P. cultrifera (55.1-59.9\% of DW) was clearly higher than those in Nereis virens (3.6-3.9\%: Lemieux et al. 1997) and L. ankyloseta (7.7\%: Balasubramanian et al. 2012). In other worms protein seems to be lower, like in $P$. anomala (56.2-66.5\%: Dorgham et al. 2014), in small and large worms of $P$. helleri (670-690 $\mathrm{g} \mathrm{kg}^{-1}$ and $620-6460 \mathrm{~g} \mathrm{~kg}^{-1}$, respectively :Palmer et al. 2014), in Perinereis sp. and Marphysa sp. (64\% DM and $510 \mathrm{~g} \mathrm{~kg}^{-1}$ DM respectively: Meunpol et al. 2005), in Australonuphis sp. and Marphysa sanguinea $\left(750 \mathrm{~g} \mathrm{~kg}^{-1}\right.$ and $690 \mathrm{~g} \mathrm{~kg}^{-1}$ : Marsden et al. 1992), and in cultured N. virens (570$620 \mathrm{~g} \mathrm{~kg}^{-1}$ : Brown et al. 2011). Proteins are an index of food quality since they generally reflect the availability of amino acids (Marsh \& Tenore 1990, Gremare et al. 1997).

The total lipid content appeared to be variable in different polychaetes, amounting to $11.6-13.4 \%$ in P. cultrifera (present study), $13.4 \%$ in Perinereis nuntia (Limesuwatthanathamrong et al. 2012), 9.1-13\% in P. helleri (Palmer et al. 2014), 6$10.7 \%$ in P. anomala (Dorgham et al. 2014), $10.0 \%$ in Diopatra neapolitana (Luis \& Passos 1995), 9.1\% in Paradiopatra sp. (Drazen et al. 2008), 5\% in Laetmonice sp. and 3\% in Travisia sp. (Drazen et al. 2008). Other lipid contents ( $140 \mathrm{~g} \mathrm{~kg}^{-1}$ and 50 $\left.\mathrm{g} \mathrm{kg}^{-1} \mathrm{DW}\right)$ were found in Perinereis sp. and Marphysa sp. (Meunpol et al. 2005), $30 \mathrm{~g} \mathrm{~kg}^{-1}$ and $40 \mathrm{~g} \mathrm{~kg}^{-1}$ in wild Australonuphis sp. and M. sanguinea (Marsden et al. 1992), $240 \mathrm{~g} \mathrm{~kg}^{-1}$ in N. virens (Brown et al. 2011), $190 \mathrm{~g} \mathrm{~kg}^{-1}$ and 200 $\mathrm{g} \mathrm{kg}^{-1}$ in wild and cultured Nereis diversicolor (Luis \& Passos 1995, Costa et al. 2000). Although the variation in total lipids may be related to differences in the maturity stage of the nereidid species, the ecological stress in the area of study may inhibit the accumulation of lipids in P. cultrifera, particularly during the maturation time. This is in agreement with Balasubramanian $e t$ al. (2012) who proposed that the variations in the physicochemical properties influence the biochemical composition of the annelid L. ankyloseta and the state of estuarine water. The diet content of total lipid may show adverse effect on ovarian maturation and feed consumption (Wouters et al. 2001), or it may be not important, as the average lipid level in commercial broodstock diets (10\%) appears to be around 3\% higher than in grower feeds used in commercial culture ponds (Meena et al. 2013).

The profile of amino acids in P. cultrifera was different from that documented for other polychaete species. The EAA leucine and to a less extent lysine and methionine were the dominant in $P$. cultrifera, while the NEAA dominated in other species, like aspartate and alanine in $P$. anomala (Dorgham et al. 2014), glutamate, aspartate and glycine in P. helleri (Palmer 2008, Palmer et al. 2014) and alanine in Arenicola marina (Hoeger \& Abe 2004). However, both NEAA (beta-alanine, glycine, glutamate) and EAA(lysine) were abundant in Nereis japonica (Hoeger \& Abe 2004). Furthermore, arginine was among the prevalent amino acid in P. helleri and the predominant in both Australonuphis sp. and M. sanguinea (Marsden et al. 1992), while it was less important in P. cultrifera.

Despite the correlation between the amino acids in N. japonica and the ambient salinities of 12 -35 (Hoeger \& Abe 2004), this correlation was not observed for $P$. cultrifera in our study, except that at $P<0.05$ of tyrosine and proline with temperature $(\mathrm{r}=0.976$ and -0.968$)$, aspartate with $\mathrm{pH}(\mathrm{r}=-0.956)$, glycine with DO (0.954), Cystine and Glutamate with BOD. Meanwhile, the amino acids exhibited slight seasonal differences in the study area regardless of the wide variations of both temperature $\left(18.9-28.9^{\circ} \mathrm{C}\right)$ and salinity (24.4-39.8). The negligible variations in some amino acids in marine bivalves indicate their stability at salinity above 20 (Kube et al. 2007).

Essential amino acids like leucine can stimulate protein synthesis (Volek 2009), lysine and tyrosine have essential roles in reproductive functions and nutrition of developing gametes (Fischer et al. 1996, Hoeger \& Abe 2004). On the other hand, the NEAAs alanine, proline and glycine are considered as osmolytes in P. cultrifera (Jeuniaux et al. 1961) and in other polychaetes and marine invertebrates (Hoeger \& Abe 2004, Kube et al. 2007). Alternatively, serine is involved in methyl group transfer, which is responsible for different processes in the cell and contributes to the formation of $S$-adenosylmethionine, the methyl donor (Amelio et al. 2014).

The abundance of fatty acids in $P$. cultrifera during the present study appeared to be affected by the temperature, particularly the unsaturated acid, C20:5n-3 (EPA), which increased with decreasing temperature during autumn-winter and vice versa in spring-summer. Luis \& Passos (1995) reported that the degree of unsaturation in $N$. diversicolor seems to be affected by environmental temperature, while Palmer et al. (2014) proposed that higher ratios of EPA occurred under natural conditions. On the other hand, the feeding habit of polychaetes may influence the amount of their fatty acid contents, particularly EPA that is common in marine diatoms and algae (e.g., Wen \& Chen 2003, 
Pratoomyot et al. 2005, Dawczynski et al. 2007, Van Ginneken et al. 2011, Pereira et al. 2012). Algae and diatoms were frequently recorded as the natural food of $P$. cultrifera in different localities (Fauchald \& Jumars 1979, Marsh \& Tenore 1990, Trueblood et al. 1994) and in our area, and this explains the high amount of EPA during the present study. High level of EPA in $P$. cultrifera was reported also in $P$. helleri grown in sand filters of mariculture wastewater and feed predominantly on microalgae (Palmer et al. 2014).

The present study revealed that $P$. cultrifer $a$ was characterized by the highest content of EPA when compared with other polychaete species (see table 10 given by Palmer et al. 2014). Such condition may assign this worm as a preferable source of EPA. However, it is necessary to take into consideration not only the individual levels of HUFAs but also the correct ratio among them (ARA/EPA/ DHA) (Suloma \& Ogata 2012). Highly unsaturated fatty acids (HUFA), especially 20:5n-3 and 22:6n3 , may be important component of live and formulated maturation diets causing their abundance in ovarian tissues (Meena et al. 2013) and diets deficient in n-3 HUFA displayed a negative effect on ovarian development, fecundity and egg quality (Wouters $e t$ al. 1999).

Palmitic acid was reported as the most prevalent saturates in many polychaete species followed by stearic acid (Palmer et al. 2014), but stearic acid was the dominant saturates in P. cultrifera, particularly due to the environmental stress of the terrestrial discharge on the area of study.

The present study revealed that the biochemical composition of $P$. cultrifera collected from the Alexandria coast was quite different from other polychaete species but generally it may be very suitable for use as feed in aquaculture. It had high levels of carbohydrate, lipids, and protein that were comparable with our previous work on P. anomala from the same area. Perinereis cultrifera was characterized by having particularly high levels of EPA at certain times of the year, making it a useful supplement in this fatty acid for a vast array of species currently cultured around the world.

\section{ACKNOWLEDGMENT}

This work has been done in the laboratory of the Oceanography Department, Faculty of Science, Alexandria University, Egypt.

\section{LITERATURE CITED}

Amelio I, F Cutruzzola, A Antonov, M Agostini \& G Melino. 2014. Serine and glycine metabolism in cancer. Trends in Biochemical Sciences 30(4): 191-198.
Baert JL \& MC Slomianny. 1987. Heterosynthetic origin of the major yolk protein, vitellin, in a nereid, Perinere is cultrifera (polychaete annelid). Comparative Biochemistry and Physiology, Part B 88(4): 1191-1199.

Balasubramanian $R$, $R$ Tamilarasan, $R$ Babu \& $D$ Varadharajan. 2012. Biochemical changes with influence of nutrient in polychaetes Laeonereis ankyloseta, south east coast of India. Archives of Applied Science Research 4(4): 1869-1879.

Bell JG \& JR Sargent. 2003. Arachidonic acid in aquaculture feeds: current status and future opportunities. Aquaculture 218: 491-499.

Bischoff AA, P Fink \& U Waller. 2009. The fatty acid composition of Nereis diversicolor cultured in an integrated recirculated system: Possible implications for aquaculture. Aquaculture 296: 271-276.

Bligh EG \& WJ Dyer. 1959. A rapid method of total lipid extraction and purification. Canadian Journal of Physiology and Biochemistry 37: 911-917.

Brown N, S Eddy \& S Plaud. 2011. Utilization of waste from a marine recirculating fish culture system as a feed source for the polychaete worm, Nereis virens. Aquaculture 322/ 323: $177-183$

Caballero MJ, MS Izquierdo, E Kjorsvik, AJ Fernandez \& G Rosenlund. 2004. Histological alterations in the liver of sea bream, Sparus aurata L., caused by short or longterm feeding with vegetable oils. Recovery of normal morphology after feeding fish oil as the sole lipid source. Journal of Fish Diseases 27: 531-541.

Cardinaletti G, G Mosconi, R Salvatori, D Lanari, D Tomassoni, O Carnevali \& AM Polzonetti-Magni. 2009. Effect of dietary supplements of mussel and polychaetes on spawning performance of captive sole, Solea solea (Linnaeus, 1758). Animal Reproduction Science 113(14): $167-176$

Chimsung N. 2014. Maturation diets for black tiger shrimp (Penaeus monodon) broodstock: a review. Songklanakarin Journal of Science and Technology 36(3): 265-273.

Coman GJ, SJ Arnold, TR Callaghan \& NP Preston. 2007. Effect of two maturation diet combinations on reproductive performance of domesticated Penaeus monodon. Aquaculture 263: 75-83.

Costa PFE, L Narciso \& LC da Fonseca. 2000. Growth, survival and fatty acid profile of Nereis diversicolor (O.F. Muller, 1776) fed on six different diets. Bulletin of Marine Science 67: 337-343.

Crafts C, M Plante, B Bailey \& I Acworth. 2012. Sensitive analysis of underivatized amino acids using UHPLC with charged aerosol detection, 6 pp. Thermo Fisher Scientific, Chelmsford. 
Danovaro R, A Dell'Anno, D Martorano, P Parodi, ND Marrale \& M Fabiano. 1999. Seasonal variation in the biochemical composition of deep-sea nematodes: bioenergetic and methodological considerations. Marine Ecology Progress Series 179: 273-283.

Dawczynski C, R Schubert \& G Jahreis. 2007. Amino acids, fatty acids, and dietary fibre in edible seaweed products. Food Chemistry 103: 891-899.

Dhainaut A \& A Belhamra. 1986. Evidence for synthesis in vitro of neutral lipids by isolated oocytes of Perinereis cultrifera (Annelida, Polychaeta). A biochemical and autoradiographic study. International Journal of Invertebrate Reproduction and Development 10(3): 275-284.

Dorgham MM, R Hamdy, HH Al-Rashidy \& MM Atta. 2014. Seasonal changes in the biochemical components of Pseudonereis anomala (Polychaeta, Nereididae) from the Alexandria coast, Egypt. Oceanologia 56(4): 881-887.

Drazen JC, CF Phleger, MA Guest \& PD Nichols. 2008. Lipid, sterols and fatty acids of abyssal polychaetes, crustaceans, and a cnidarian from the northeast Pacific Ocean: food web implications. Marine Ecology Progress Series 372: 157-167.

Elayaraja S, N Annamalia, P Murugesan, P Mayavu \& T Balasubramnian. 2011. Effect of amylase on growth, survival and proximate composition of the polychaete, Perinereis cultrifera (Grub, 1840). Aquaculture Nutrition 17:627-633.

Fauchald K \& PA Jumars. 1979. The diet of worms: a study of polychaete feeding guilds. Oceanography and Marine Biology: An Annual Review 17: 193-284.

Fernandez C. 1998. Seasonal changes in the biochemical composition of the edible sea urchin Paracentrotus lividus Echinodermata: Echinoidea in a lagoonal environment. Marine Ecology 19(1): 1-11.

Fischer A, AWC Dorresteijn \& U Hoeger. 1996. Metabolism of oocyte construction and the origin of histospecificity in the cleaving egg. Lessons from nereid annelids. International Journal of Developmental Biology 40: 421-430.

Fontaine F, MH Gevaert \& M Porchet. 1984. Distribution of neutral lipids in coelomic constituents during oogenesis of Perinereis cultrifera (Annelida Polychaeta). Comparative Biochemistry and Physiology, Part A77(1): 45-50.

Gornall AG, CJ Bardawill \& MM David. 1949. Determination of serum proteins by means of the biureto reaction. Journal of Biological Chemistry 177: 751-766.

Gremare A, JM Amouroux, F Charles, A Dinet, C RiauxGobin, J Baudart, L Medernach, JY Bodiou, G Vetion, JC Colomines \& P Albert. 1997. Temporal change in the biochemical composition and nutritional value of the particulate organic matter available to surface depositfeeders: a two year study. Marine Ecology Progress Series 150: 195-206.
Guemouda M, Z Meghlaoui, T Daas, O Daas-Maamcha \& P Scaps. 2014. Monitoring pollution in East Algerian coasts using biochemical markers in the polychaete annelid Perinereis cultrifera. Annals of Biological Research 5(2): $31-40$.

Harrison KE. 1997. Broodstock nutrition and maturation diets. In: D'Abramo LR, DE Conklin \& DM Akiyama (eds). Advances in world aquaculture 6: Crustacean nutrition, pp. 390-408. World Aquaculture Society, Baton Rouge.

Hoeger U \& H Abe. 2004. b-Alanine and other free amino acids during salinity adaptation of the polychaete Nereis japonica. Comparative Biochemistry and Physiology, Part A 137: 161-171.

Huang JH, SG Jiang, HZ Lin, FL Zhou \& L Ye. 2008. Effects of dietary highly unsaturated fatty acids and astaxanthin on the fecundity and lipid content of pond reared Penaeus monodon (Fabricius) broodstock. Aquaculture Research 39: 240-251.

Izquierdo MS, H Fernandez-Palacios \& AGJ Tacon. 2001. Effect of broodstock nutrition on reproductive performance of fish. Aquaculture 197: 25-42.

James C. 1995. Analytical chemistry of food, 178 pp. Blackie Academic \& Professional Press, London.

Jeuniaux C, S Bricteaux-Gregoire \& M Florkin. 1961. Contribution des acides amines libres a la regulation osmotique intracellulaire chez deux crustacés euryhalines, Leander serratus. F. et Leander squilla L. Cahiers de Biologie Marine 11:373-379.

Kube S, A Sokolowski, JM Jansen \& D Schiedek. 2007. Seasonal variability of free amino acids in two marine bivalves, Macoma baltica and Mytilus spp., in relation to environmental and physiological factors. Comparative Biochemistry and Physiology, Part A 147: 1015-1027.

Lemieux H, PU Blier, F Dufresne \& G Desrosiers. 1997. Metabolism and habitat competition in the polychaete Nereis virens. Marine Ecology Progress Series 156: 151-156.

Limesuwatthanathamrong M, S Sooksai, S Chunhabundit, S Noitung, N Ngamrojanavanich \& A Petsom. 2012. Fatty acids profile and lipids compositions in Perineries nuntia, the diet for marine shrimp. Asian Journal of Animal Sciences 6(2): 65-75.

Luis OJ \& AM Passos. 1995. Seasonal changes in lipid content and composition of the polychaete Nereis (Hediste) diversicolor. Comparative Biochemistry and Physiology, Part B 111:576-586.

Marsden G, JM McGuren, HZ Sarac, AR Neill, IJ Brock \& CL Palmer. 1992. Nutritional composition of some natural marine feeds used in prawn maturation. In: Allan GL \& W Dall (eds). Proceedings of Aquaculture Nutrition Workshop, Salamander Bay, 15-17 April 1991. NSW Fisheries, Brackish Water Fish Culture Research Station, Salamander Bay, Australia, pp. 82-86. 
Marsh AG \& KR Tenore. 1990. The role of nutrition in regulating the population dynamics of opportunistic, surface deposit feeders in a mesohaline community. Limnology and Oceanography 35: 710-724.

Mayzaud P, P Virtue \& E Albessard. 1999. Seasonal variations in the lipid and fatty acid composition of the euphausiid Meganyctiphanes norvegica from the Ligurian Sea. Marine Ecology Progress Series 186: 199-210.

Meena DK, P Das, MS Akhtar, M Sekar \& S Kumar. 2013. Broodstock nutrition and management in Crustacean. Aquafind. <aquafind.com/articles/Broodstock-Nutrition-InCrustacean.php $>$

Meunpol O, P Meejing \& S Piyatiratitivorakul. 2005. Maturation diet based on fatty acid content for male Penaeus monodon (Fabricius) broodstock. Aquaculture Research 36: 1216-1225.

Musmeci MT \& V Damelio. 1985. Erythrocruorin subunits of Perinereis cultrifera Grube (Annelida, Polychaeta) compared with other erythrocruorins. Italian Journal of Zoology 52(3-4): 211-217.

Nguyen BT, S Koshio, K Sakiyama, M Ishikawa, S Yokoyama \& MA Kader. 2012. Effects of polychaete extracts on reproductive performance of kuruma shrimp, Marsupenaeus japonicus Bate. Part II. Ovarian maturation and tissue lipid compositions. Aquaculture 334/337: 65-72.

Olive PJW. 1999. Polychaete aquaculture and polychaete science: a mutual synergism. Hydrobiologia 402: 175-183.

Palacios E, AM Ibarra, JL Ramirez, G Portillo \& IS Racotta. 1998. Biochemical composition of eggs and nauplii in Pacific White Shrimp, Penaeus vannamei Boone, in relation to the physiological condition of spawners in a commercial hatchery. Aquaculture Research 29: 183-189.

Palacios E, CI Perez-Rostro, JL Ramirez, AM Ibarra \& IS Racotta. 1999. Reproductive exhaustion in shrimp Penaeus vannamei reflected in larval biochemical composition, survival and growth. Aquaculture 171:309-321.

Palmer PJ. 2008. Polychaete-assisted sand filters - prawn farm wastewater remediation trial. National Landcare Programme Innovation Grant No. 60945, Technical Report, pp. 1-61. <http://nrmonline.nrm.gov.au/downloads/mql:2538/content>

Palmer PJ. 2010. Polychaete-assisted sand filters. Aquaculture 306: 369-377.

Palmer PJ. 2011. Commercial application of polychaete sand filters for wastewater remediation and broodstock feeds: Landcare Sustainable Practices Grant No. SEQC1418, Technical Report, pp. 1-34. Department of Employment, Economic Development and Innovation (DEEDI), Queensland. <http://era.daf.qld.gov.au/2038/>

Palmer PJ, S Wang, A Houlihan, I Brock. 2014. Nutritional status of a nereidid polychaete cultured in sand filters of mariculture wastewater. Aquaculture Nutrition 20(6): 675-691.
Pereira H, L Barreira, F Tabueiredo, L Custódio, C VizettoDuarte, C Polo, E Rešek, A Engelen \& J Varela. 2012. Polyunsaturated fatty acids of marine macroalgae: Potential for nutritional and pharmaceutical applications. Marine Drugs 10: $1920-1935$.

Poltana P, T Lerkitkul, P Pongtippatee-Taweepreda, S Asuvapongpattana, K Wongprasert, S Sriurairatana, J Chavadej, P Sobhon, PJW Olive \& B Withyachumnarnkul. 2007. Culture and development of the polychaete Perinereis cf. nuntia. Invertebrate Reproduction and Development 50(1): 13-20.

Porchet M \& G Spike. 1978. Biochemical analysis of Nereidae gametogenesis -I. Evolution of glycoconjugates during natural oogenesis of Perinereis cultrifera Grube (Polychaete Annelid). Comparative Biochemistry and Physiology, Part B 59(2): 175-181.

Pratoomyot J, P Srivilas \& T Noiraksar. 2005. Fatty acids composition of 10 microalgal species. Songklanakarin Journal of Science and Technology 27(6): 1179-1187.

Rossi D, A Gozzio, E Flechsig, MA Klein, T Rülicke, A Aguzzi \& C Weissmann. 2001. Onset of ataxia and Purkinje cell loss in PrP mice inversely correlated with DP1 level in brain. EMBO Journal 20: 694-702.

Shucksmith R, H Hinz, M Bergmann \& MJ Kaiser. 2006. Evaluation of habitat use by adult plaice (Pleuronectes platessa L.) using underwater video survey techniques. Journal of Sea Research 56: 317-328.

Strickland JD \& TR Parsons. 1975. A handbook of seawater analysis. Bulletin, Fisheries Research Board of Canada 167: 1-310.

Suloma A \& HY Ogata. 2012. Lipid and fatty acid composition of commercially important tropical freshwater fish gonads: Guidelines for specific broodstock diet. Turkish Journal of Fisheries and Aquatic Sciences 12: 743-749.

Thuesen E \& J Childress. 1993. Metabolic rates, enzyme activities and chemical compositions of some deep-sea pelagic worms, particularly Nectonemertes mirabilis (Nemertea; Hoplonemertinea) and Poeobius meseres (Annelida; Polychaeta). Deep-Sea Research 40(5): 937-951.

Trueblood DD, ED Gallagher \& DM Gould. 1994. Three stages of seasonal succession on the Savin Hill Cove mudflat, Boston Harbour. Limnology and Oceanography 39: 14401454.

Van Ginneken VJT, JPFG Helsper, W de Visser, H van Keulen \& WA Brandenburg. 2011. Polyunsaturated fatty acids in various macroalgal species from north Atlantic and Tropical seas. Lipids in Health and Disease 10: 104. <doi: 10.1186/1476-511X-10-104>

Volek JS. 2009. Additional leucine not required for whey protein. Applied Physiology, Nutrition and Metabolism 34(2): 151-161. 
Wen Z \& F Chen. 2003. Heterotrophic production of eicosapentaenoic acid by microalgae. Biotechnology Advances 21(4): 273-294.

Wouters R, L Gomez, P Lavens \& J Calderon. 1999. Feeding enriched Artemia biomass to Penaeus vannamei broodstock: its effect on reproductive performance and larval quality. Journal of Shellfish Research 18: 651-656.
Wouters R, L Bastidas, J Calderón \& P Sorgeloos. 2001.

Ovarian maturation and haemolymphatic vitellogenin concentration of Pacific white shrimp Litopenaeus vannamei (Boone) fed increasing levels of total dietary lipids and HUFA. Aquaculture Research 32: 573-582.

Received 27 October 2014 and accepted 28 August 2015

Editor: Claudia Bustos D. 